\title{
Human Bocavirus 1 Infection: Clinical Cases
}

\author{
Nicolas Sebastian Wasinger ${ }^{1}$, Ariana Lucia Marchesi ${ }^{1}$, Lucia Maria Ghietto ${ }^{1}$, Sabrina Rivadera ${ }^{1}$, Agustina \\ Cardozo Tomas ${ }^{1}$, Leticia Eguizabal ${ }^{2}$, Veronica Kohn ${ }^{2}$, Fanny Arroyo ${ }^{2}$, Daniel Quiroga ${ }^{2}$, Laura Moreno ${ }^{2}$, Maria \\ Pilar Adamo ${ }^{1^{*}}$ \\ ${ }^{1}$ Instituto de Virología Dr. J M Vanella, Facultad de Ciencias Médicas, Universidad Nacional de Córdoba. \\ ${ }^{2}$ Catedra de Clínica Pediátrica, Facultad de Ciencias Médicas, Universidad Nacional de Córdoba y Hospital de Niños de la Santísima Trinidad de \\ Córdoba.
}

Received: October 26, 2017; Accepted: November 21, 2017; Publishing date: November 28, 2017

*Corresponding author: Maria Pilar Adamo, Instituto de Virología Dr. J M Vanella, Facultad de Ciencias Médicas, Universidad Nacional de Córdoba, Tel: +54 351 4334022; E-mail: mpadamo@fcm.unc.edu.ar

\begin{abstract}
Human Bocavirus 1 (HBoV1) is a parvovirus associated with acute lower respiratory tract infection (LRTI). This study describes the clinical picture of HBoV1 infection at high viral load in infants without coinfections or comorbidities. Patients less than 5 years old admitted for LRTI at the Children's Hospital of Cordoba, Argentina, were prospectively screened for HBoV1 by PCR. HBoV1 genome load in respiratory secretion was determined by qPCR and clinical and epidemiological data were collected in ad-hoc forms. We identified 7 patients with $\mathrm{HBoV} 1$ infection with clinical specimens collected within $24 \mathrm{~h}$ of admission, high viral load, no codetection, no comorbidity and complete medical records. Other than the age ( 6 patients were $\leq 6$ months) no outstanding risk factors were recognized. Wheezing and hypoxemia were present together in the majority of the patients $(6 / 7,86 \%)$. Lung infiltrates confirmed pneumonia in $5 / 7(71 \%)$ patients. The average hospital stay was $5.9 \pm 3.0$ days; none died and no additional complications were registered at discharged. Compared to RSV, the clinical picture showed differences only respect to days of oxygen therapy ( $\mathrm{p}=0.0004)$ and hospital stay $(\mathrm{p}=0.036)$. Consequently, when other pathogens have been ruled out, testing HBoV1 in infants hospitalized with LRTI can contribute to improve patient care.
\end{abstract}

Keywords: HBoV1; High Viral Load; Pneumonia; Infant; Comorbidity;

\section{Introduction}

Human Bocavirus 1 (HBoV1) is a parvovirus associated with acute lower respiratory tract infection (LRTI), which is a main cause of morbimortality in children around the world [1,2]. HBoV1 detection rate varies widely from less than 1 to more than $30 \%$ but usually it is a frequent virus in infants with acute respiratory disease [3-10]. IgG prevalence screening among young adults indicates that the virus is widely distributed in the human population and pre-school aged children are the major susceptible group [11]. The role of HBoV1 as an independent causal agent in acute respiratory disease has been discussed due to the high codetection rate and the detection of the viral genome in asymptomatic individuals [3,12-17]. However, both findings are now postulated to be linked to the virus persistence in the respiratory tract $[3,18]$. Retrospective studies based on detection of HBoV1 infection and its correlation with signs and symptoms registered at the events of positive samples showed that the primary infection causes illness in children $[19,20]$. Additionally, symptoms have been shown to depend on high viral loads $[10,21$ 24]. However, HBoV1 natural history of infection and the genuine clinical manifestations associated remain challenging, especially in the scenario of a persistent infection. In this study, we describe the clinical cases of high viral load-HBoV1 infection in infants without coinfections and comorbidities, hospitalized for acute lower respiratory tract disease.

\section{Material and Methods}

\section{Study population}

Patients less than 5 years old admitted for LRTI at the Children's Hospital Santísima Trinidad of Cordoba city, Argentina, from January 1, 2011, to December 31, 2013, were included. Clinical diagnosis and recording of cases were performed by physicians at the hospital. Nasopharyngeal aspirate and blood samples were obtained for detection of common respiratory viruses and bacteria, as part of the routine medical practice and surveillance of respiratory viruses (situation room). HBoV1 was assayed by molecular technique in the respiratory sample. Regardless of this study, patients were treated according to the guidelines of the hospital. Clinical and epidemiological data of the patients were registered in ad-hoc forms at the time of admission. The forms were completed with information obtained from the medical records. These contained the following information: age, sex, date of entry and exit (days of hospitalization), date of collection of clinical specimens, leukocyte count, Erythrocyte Sedimentation Rate (ESR); signs and symptoms: fever (temperature $\geq 38.5^{\circ} \mathrm{C}$ ), cough, rhinitis, cyanosis, apnea, wheezing, emesis, diarrhea, rash; risk factors: including previous episodes of LRTI and 
hospitalization, breastfeeding, passive smoking, contact with person with symptoms of respiratory infection, nutritional status, environmental pollution, overcrowding in housing, vaccines, attendance at daycare, family history of asthma, atopy, personal risk factors; diagnosis on admission; chest X-ray; treatments (oxygen therapy, mechanical ventilation, antibiotics, antivirals, other treatments); results of blood culture and diagnosis by immunofluorescence [Respiratory Syncytial Virus (RSV), ParaInfluenza 1, 2 and 3 (PI), Influenza A and B (FLU), Adenovirus (ADV) and Meta Pneumo Virus (MPV)]; complications (admission at ICU, death); and diagnosis at discharge. Cases with incomplete medical history were not considered in the analysis. The following criteria were considered to include patients for the analysis of HBoV1 associated clinical manifestations: high viral load of HBoV1, clinical samples obtained within $24 \mathrm{~h}$ of admission, no positive detection in the blood culture test or in the detection of any other viruses, no comorbidities (congenital, chronic, or immunodeficiency conditions).

\section{HBoV1 Detection}

Respiratory secretions were vortex with $1 \mathrm{ml}$ phosphate buffer solution (PBS) and glass beads. After centrifuging at $1000 \mathrm{rpm}$ for $5 \mathrm{~min}$ the pellet was suspended in $500 \mu \mathrm{PBS}$ and $200 \mu \mathrm{l}$ of this suspension was used to extract nucleic acid with guanidinium buffer and silica [25]. Briefly, this technique implies treating the sample with with a strong chaotropic agent and allowing the binding of nucleic acids to silica particles in a low pH-buffer. After several washings with ethanol and acetone, the extracts are completely dried and recovered in TE bufer ( $\mathrm{pH}$ 8.0) at $56^{\circ} \mathrm{C}$. A 2- $\mu$ l aliquot of nucleic acid extract was used as template in the PCR assay, which amplified a region of HBoV1 NP1 using primers and Taq polymerase from Invitrogen / Thermo Fisher. The forward and reverse primers had the following sequences and positions: 5'-GAGCTCTGTAAGTACTATTAC, nucleotides 2351 to 2371, and 5'-CTCTGTGTTGACTGAATACAG, nucleotides 2704 to 2684, respectively, on the GenBank sequence with accession number accession number DQ000496 [26]. The PCR products were resolved in $10 \%$ polyacrylamide gel electrophoresis and visualized after $0.011 \mathrm{M}$ silver staining. These protocols were described previously $[27,28]$.

\section{Quantification of HBoV1-Positive Specimens}

Real-time PCR was performed as described before, using the NP1 gene as the target for HBoV1 relative quantification [10]. The $25 \mu \mathrm{L}$ amplification reaction contained $2.5 \mu \mathrm{L}$ of DNA sample, $5 \mathrm{U} / \mu \mathrm{L}$ Platinum Taq DNA polymerase (Invitrogen / Thermo Fisher), $0.04 \mu \mathrm{M}$ of each primer and $0.1 \mu \mathrm{L}$ of a $1 / 100$ SYBR green (Invitrogen S-7563) dilution in DMSO. Viral load in each sample was estimated according to the 2-ddCt-method and the patients were classified in two categories: low viral load (fold change value 0-49.9) and high viral load (fold change value $=50$ ).

\section{Analysis of Data}

Variables were expressed by measures of central tendency, standard deviation, range, frequency and 95\% confidence intervals $(95 \% \mathrm{CI})$ as appropriate. Statistical tests to determine significant differences: non-parametric Wilcoxon-Mann Whitney and Fisher $(\alpha=0.05)$.

\section{Ethical Approval}

The protocol was approved by the Institutional Ethics Committee for Research in Human Health (CIEIS del Niño y el Adulto del Polo Hospitalario Cordoba) and was carried out according to current regulations, including informed consent of participants.

\section{Results}

The study sample included 1416 clinical specimens from 1206 patients, 228 in 2011, 351 in 2012 and 627 in 2013. Of these, 151 (12.5\%) were positive for HBoV1, 16/228 (7\%) in 2011, 50/351 (14.4\%) in 2012 and 85/627 (13.6\%) in 2013.

HBoV1 was detected throughout the entire period studied, although most cases occurred during the fall season (Fig.1). Among the HBoV1-positive patients, 72/151 (47.7\%) had no evident coinfection with other respiratory pathogen and 48 of these had complete medical records. We excluded 8 patients with comorbidites (asthma, heart disease, Down syndrome and nephrotic syndrome) from this last group and in the remaining 40 only 7 patients had high viral load, which constituted the final study sample.

Epidemiological features of the study group and clinical presentation of HBoV1 infection. The majority of the cases were infants of 6 months or less $(6 / 7,85.7 \%)$ with no other outstanding risk factors (Table 1). Blood tests showed leukocytosis in 4/7 (57\%) patients (average count $23125 \pm 3559$ / mm3, range: 19150 - 27000, 95\% CI: 21346 - 24905) and high ESR in 3/7 (43\%) patients (average $42 \pm 14 \mathrm{~mm} / \mathrm{h}$, range: $26-50,95 \% \mathrm{CI}$ : 35 - 50). As shown in Table 2, wheezing, coughing and fever were the most frequent clinical manifestations. Most patients were admitted with a diagnosis of bronchiolitis and required oxygen therapy (although none needed mechanical ventilation). Chest $\mathrm{X}$-ray images indicate the presence of infiltrates corresponding to a radiological diagnosis of pneumonia in the majority of the patients, while the presence of air trapping confirmed the diagnosis of bronchiolitis in 1 patient. The average hospital stay was $5.9 \pm 3.0$ days; none died and no other complications were registered at discharged. A comparison of $\mathrm{HBoV} 1$ clinical picture to that of an equivalent group of RSV infection showed significant differences only respect to number of days of oxygen therapy ( 4.2 \pm 2.0 vs $8.7 \pm 8.0$, respectively, $\mathrm{p}=0.0004$ ) and days of hospital stay ( $5.9 \pm 3.0$ vs $9.0 \pm 6.0$, respectively, $p=0.036$ ); all other features were similar.

The risk factors and clinical presentation in patients with the first episode of LRTI and hospitalization were compared to those in patients who had previous LRTI events (Tables 1 and 2). A tendency to increased personal risk factors among patients with previous LRTI episodes was noticed, as well as more days of oxygen therapy and longer hospital stay among first-episode LRTI patients. However, no statistically significant differences were observed between these two groups. 
Table 1: Demographic and epidemiological risk factors of previously healthy pediatric patients hospitalized for LRTI with single HBoV1 infection at high viral load. The study group ( $\mathrm{n}=7$ ) was classified in the subgroups of patients presenting with the first episode of LRTI (n=4) and patients with previous episodes of LRTI $(n=3)$.

\begin{tabular}{|c|c|c|c|}
\hline & HBoV1 (n=7) & HBoV1-First LRTI Episode (n=4) & $\begin{array}{c}\text { HBoV1-with Previous LRTI } \\
\text { Episodes }(n=3)\end{array}$ \\
\hline \multicolumn{4}{|l|}{ Demographic data } \\
\hline Proportion of male children & $5 / 7(71 \%)$ & $3 / 4(75 \%)$ & $2 / 3(67 \%)$ \\
\hline \multicolumn{4}{|l|}{ Age (months) } \\
\hline Range & $1-29$ & $1-6$ & $2-29$ \\
\hline Average \pm SD & $7.0 \pm 9.9$ & $3.0 \pm 2.2$ & $12.0 \pm 14.6$ \\
\hline Median & 3 & 3 & 6 \\
\hline \multicolumn{4}{|l|}{ Epidemiological risk factors } \\
\hline Lack of breastfeeding & $3 / 7(43 \%)$ & $2 / 4(50 \%)$ & $1 / 3(33 \%)$ \\
\hline Malnutrition & 0 & 0 & 0 \\
\hline Personal risk factors ${ }^{1}$ & $3 / 7(43 \%)$ & $1 / 4(25 \%)$ & $2 / 3(67 \%)$ \\
\hline Atopy & 0 & 0 & 0 \\
\hline Family history of asthma & 0 & 0 & 0 \\
\hline Passive smoking & $2 / 7(29 \%)$ & 0 & $2 / 3(67 \%)$ \\
\hline Overcrowding in housing & 0 & 0 & 0 \\
\hline $\begin{array}{l}\text { Contact with symptomatic } \\
\text { person (LRTI) }\end{array}$ & $1 / 7(14 \%)$ & 0 & $1 / 3(33 \%)$ \\
\hline $\begin{array}{l}\text { Incomplete vaccine } \\
\text { schedule }\end{array}$ & $4 / 7(57 \%)$ & $2 / 4(50 \%)$ & $2 / 3(67 \%)$ \\
\hline Daycare & 0 & 0 & 0 \\
\hline Environmental pollution & $2 / 7$ (29\%) & 0 & $2 / 3(67 \%)$ \\
\hline
\end{tabular}

Table 2:Clinical characteristics of previously healthy pediatric patients hospitalized for LRTI with single HBoV1 infection at high viral load. The study group ( $n=7)$ was classified in the subgroups of patients presenting with the first episode of LRTI $(n=4)$ and patients with previous episodes of LRTI $(n=3)$.

\begin{tabular}{|l|c|c|c|}
\hline & HBoV1 (n=7) & HBoV1-First LRTI Episode (n=4) & $\begin{array}{c}\text { HBoV1-with Previous LRTI } \\
\text { Episodes (n=3) }\end{array}$ \\
\hline $\begin{array}{l}\text { Clinic } \\
\text { Signs and symptoms }\end{array}$ & \multicolumn{2}{|c|}{} \\
\hline Wheezing & $6 / 7(86 \%)$ & $4 / 4(100 \%)$ & $2 / 3(67 \%)$ \\
\hline Coughing & $5 / 7(71 \%)$ & $2 / 4(50 \%)$ & $3 / 3(100 \%)$ \\
\hline Fever & $3 / 7(43 \%)$ & $2 / 4(50 \%)$ & $1 / 3(33 \%)$ \\
\hline Rhinitis & $2 / 7(29 \%)$ & $2 / 4(50 \%)$ & 0 \\
\hline Cyanosis & $1 / 7(14 \%)$ & $1 / 4(25 \%)$ & 0 \\
\hline Subcrepitant rales & $1 / 7(14 \%)$ & $1 / 4(25 \%)$ & 0 \\
\hline Diarrhea & $1 / 7(14 \%)$ & $1 / 4(25 \%)$ & $1 / 3(33 \%)$ \\
\hline Apnea & $2 / 7(29 \%)$ & $2 / 4(50 \%)$ & 0 \\
\hline Rhonchus & 0 & 0 & 0 \\
\hline Suffocation & $1 / 7(14 \%)$ & 0 & $1 / 3(33 \%)$ \\
\hline Intercostal retraction & $2 / 7(29 \%)$ & $2 / 4(50 \%)$ & 0 \\
\hline
\end{tabular}




\begin{tabular}{|c|c|c|c|}
\hline Tachypnea & $1 / 7$ (14\%) & $1 / 4(25 \%)$ & 0 \\
\hline \multicolumn{4}{|l|}{ Diagnosis on admission } \\
\hline Bronchiolitis & $7 / 7(100 \%)$ & $4 / 4(100 \%)$ & $3 / 3(100 \%)$ \\
\hline Pneumonia & 0 & 0 & 0 \\
\hline \multicolumn{4}{|l|}{ Chest radiography } \\
\hline Interstitial infiltr0ate & $3 / 7(43 \%)$ & $2 / 4(50 \%)$ & $1 / 3(33 \%)$ \\
\hline Interstitial alveolar infiltrate & $1 / 7(14 \%)$ & 0 & $1 / 3(33 \%)$ \\
\hline Alveolar infiltrate & $1 / 7(14 \%)$ & $1 / 4(25 \%)$ & 0 \\
\hline Air trapping & $1 / 7(14 \%)$ & 0 & $1 / 3(33 \%)$ \\
\hline Bronchial wall thickening & $1 / 7(14 \%)$ & $1 / 4(25 \%)$ & 0 \\
\hline \multicolumn{4}{|l|}{ Therapy } \\
\hline Oxygen requirement & $6 / 7(86 \%)$ & $3 / 4(75 \%)$ & $3 / 3(100 \%)$ \\
\hline Range (days) & $2-7$ & $4-6$ & $2-7$ \\
\hline Average time \pm SD & $4.2 \pm 2.0$ & $4.7 \pm 1.2$ & $3.7 \pm 2.9$ \\
\hline $95 \% \mathrm{CI}$ & $3.4-5.0$ & $4.1-5.4$ & $2.1-5.4$ \\
\hline Mechanical ventilation & 0 & 0 & 0 \\
\hline Antibiotics & $6 / 7(86 \%)$ & $4 / 4(100 \%)$ & $2 / 3(67 \%)$ \\
\hline Antiviral (oseltamivir) & $3 / 7(43 \%)$ & $1 / 4(25 \%)$ & $2 / 3(67 \%)$ \\
\hline Complications & 0 & 0 & 0 \\
\hline \multicolumn{4}{|l|}{ Hospitalization } \\
\hline Range (days) & $2-9$ & $5-9$ & $2-6$ \\
\hline Average \pm SD & $5.9 \pm 3.0$ & $7.0 \pm 1.8$ & $4.3 \pm 4.0$ \\
\hline $95 \% \mathrm{CI}$ & $5.5-6.4$ & $6.7-7.3$ & $3.7-5.0$ \\
\hline \multicolumn{4}{|c|}{ Diagnosis based on chest X-ray } \\
\hline Bronchiolitis & $2 / 7(29 \%)$ & $1 / 4(25 \%)$ & $1 / 3(33 \%)$ \\
\hline Pneumonia & $5 / 7(71 \%)$ & $3 / 4(75 \%)$ & $2 / 3(67 \%)$ \\
\hline
\end{tabular}

\section{Discussion}

In this report, we describe a case series study of high viral load HBoV1 infection in previously healthy children hospitalized for acute LRTI. The prospective selection of clinical situations and individualized recording of each case allowed documenting quality data. In addition, the detection of HBoV1 was done by means of NP1 gen detection in conventional PCR. This diagnosis methodology is convenient for being it is highly specific (no other human bocaviruses are amplified) and at the same time sensitive (demonstrated by the qPCR, as most of the cases were low viral load infections) [29].

One limitation of this study that could be considered is the lack of detection of other respiratory agents by molecular method. However, it is important to note that only selected cases of HBoV1 infection were analyzed (high viral load, no comorbidity). It has been observed that respiratory codetections are very frequent and the etiological participation of the different coinfecting agents is not easy to discern $[30,31]$. Thus, the detection of common respiratory agents by immunofluorescence is still preferred in some clinical settings, since due to its lower sensibility it can indicate cases of at high viral load.
The age of the patients in the study group shows that HBoV1 infection capable of causing severe acute respiratory illness occurs early in life, including the neonatal and breastfeeding period (Table 1). The group of incidence is similar to other significant respiratory pathogens in infants, such as RSV and PI viruses [32]. Accordingly, HBoV1 infection in very young children can relate to the immaturity of the innate immune response, which renders them more susceptible to respiratory infections during the first months of life $[33,34]$. The event of infection in newborns and young infants has been reported previously and raises questions concerning the presence of maternal antibodies with effective protection in this age group $[10,24,35]$. In this regard, serological studies initially indicated that around 100\% of the adults had antibodies against human bocavirus, which led to propose that newborns are protected by maternal antibodies [36-38]. Recently, however, cross reactions and a phenomenon called "original antigenic sin" have been reported to occur among different types of human bocaviruses (at present 4 genotypes have been identified: HBoV1 associated with respiratory infection and HBoV2-4 associated with infection of the enteric tract but currently not related to disease) [11,39-41]. As a result, infection with one $\mathrm{HBoV}$ type induces antibodies that can 
react with a different type of HBoV. Thus, the seroprevalence of HBoV1 in adults is actually lower than originally thought (60$70 \%)$. Also, a previous infection with one HBoV type can make a child not to launch antibody response when he or she contracts infection by a second type of $\mathrm{HBoV}$. These facts could explain our findings of HBoV1 infection in the first 6 months of life in spite of breastfeeding. Alternatively, our observations could suggest a short incubation time, rapid colonization of the respiratory tract and onset of the illness, in which case serum immunoglobulins would have a limited role in the control of infection -although viral DNA has been demonstrated in serum and thus the infection is not strictly localized $[1,6,19,42]$. Contact with symptomatic person was observed in one case only (Table 1), which could imply contagion from asymptomatic individuals; otherwise, it can be proposed, considering the physical properties of the family Parvoviridae, that the viral particle remains infectious in the environment for long periods.

Regarding the clinical picture, the majority of the patients presented wheezing, coughing and hypoxemia at the time of admission. The chest X-ray images displayed lung infiltrates in $80 \%$ cases, framed in the pattern of viral pneumonia. The average stay at the hospital was $5.9 \pm 3.0$ days after which all patients were discharged without complications (Table 2). Thus, radiologically confirmed pneumonia was the predominant diagnosis and the clinical presentation of HBoV1 infection in infants fits into the overall picture of LRTI caused by other common viral respiratory pathogens of medical importance in this age group $[2,43]$. HBoV1 infection differed from RSV infection only respect to the number of days of oxygen and hospitalization. Taking into account that HBoV1 is a prevalent virus in children and the infection can be as severe as that caused by other common respiratory viral pathogens, HBoV1 diagnosis could be considered in infants hospitalized with LRTI, especially when other agents have been ruled out. In this matter, note that $86 \%$ of the patients were treated with antibiotics (Table 2). This is a common situation with young children hospitalized for LRTI and it is noteworthy to mention that the results of this study were not available to the physicians until after discharge. But it has been shown recently that the proportion of community acquired pneumonia (CAP) of viral origin exceeds by far that of bacterial CAP in children less than 5 years old, addressing the need to re-evaluate the empiric use of antimicrobial treatment in this age group [44]. The diagnosis of HBoV1 not only could assist in the medical management of the patient but also contribute to surveillance of respiratory viruses, since the increased frequency of cases in the cold months (Figure 1) accompanies the seasonal peak of other respiratory viruses such as RSV and FLU $[45,46]$.

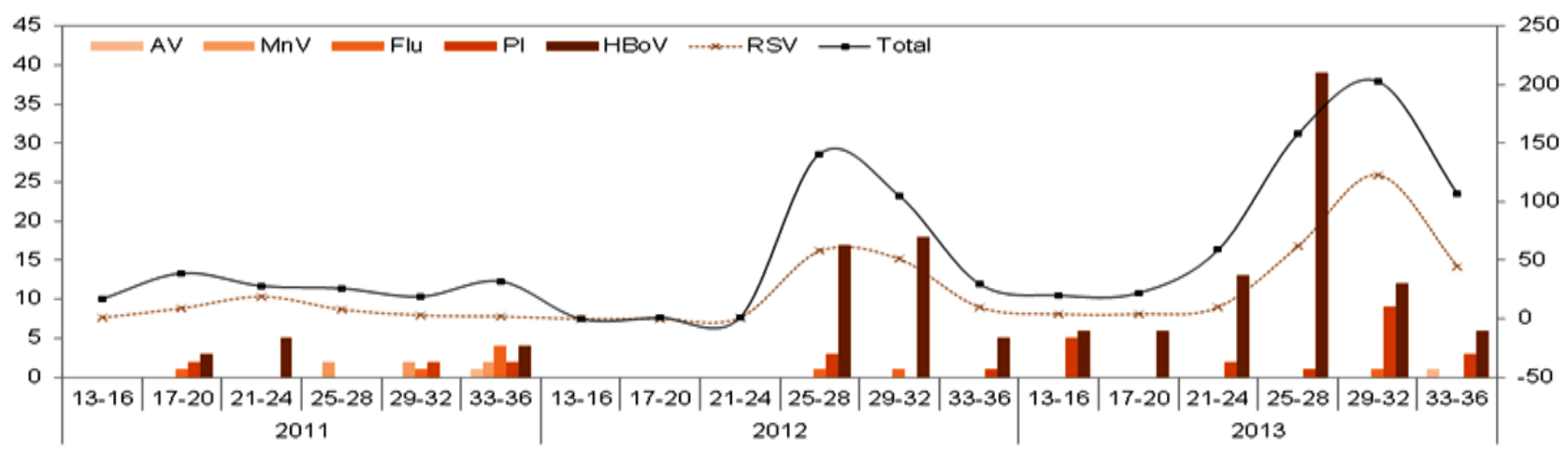

Figure 1: Children less than 5 years old admitted at the Children's Hospital of Cordoba, Argentina, with lower acute respiratory tract infection, during fall and winter (epidemiological weeks 13 through 36), 2011 - 2013. In this period occurred the majority of the cases studied (1008/1206, 83.6\%) and HBoV1 detections $(134 / 151,88.7 \%)$. The $y$-axes show absolute numbers, the left one for bars and the right one for lines

Recurrent episodes of LRTI might indicate a special susceptibility to respiratory infections and pathogens such as RSV or FLU can cause a severe illness depending on genetic risk factors that turn the host more vulnerable $[47,48]$. Therefore, patients with first-episode LRTI were compared to patients who had previous episodes of LRTI and hospitalization (Tables 1 and 2). We could not identify any significant differences in the course of infection in these two groups, although the number of cases studied was too small. In order to elucidate the factors involved in the balance of HBoV1 infection a bigger sample of patients meeting the inclusion / exclusion criteria used here is needed. For this reason, and given the high percent of codetection and low viral load HBoV1 infections, more studies of this type with large numbers of patients tested are justified.
In conclusion, high viral load infection of the lower respiratory tract by HBoV1 in previously healthy infants generally presented with wheezing, hypoxemia and cough; the prevalent diagnosis was pneumonia (interstitial and alveolar infiltrates) with good evolution. Future research focused in the natural history of HBoV1 as well as virus-host interactions will allow establishing a practical method to diagnose the infection in the context of illness.

\section{Acknowledgements}

This study was performed with funds granted from Fundacion A. J. Roemmers 2012-2014 and SeCyT-UNC 05/H363. 


\section{References}

1. Broccolo F, Falcone V, Esposito S, Toniolo A. Human bocaviruses: Possible etiologic role in respiratory infection. J Clin Virol. 2015;72:7581. doi:10.1016/j.jcv.2015.09.008

2. WHO. WHO | Children: reducing mortality. World Health Organization.

3. Martin ET, Fairchok MP, Kuypers J, Magaret A, Zerr DM, Wald A et al. Frequent and prolonged shedding of bocavirus in young children attending daycare. J Infect Dis. 2010;201(11):1625-1632. doi:10.1086/652405

4. Bicer S, Giray T, Çöl D, Erdağ GÇ, Vitrinel A, Gürol Y, et al. Virological and clinical characterizations of respiratory infections in hospitalized children. Ital J Pediatr 2013;39:22. doi:10.1186/1824-7288-39-22

5. Don M, Söderlund-Venermo M, Valent F, Lahtinen A, Hedman L, Canciani M, et al. Serologically verified human bocavirus pneumonia in children. Pediatr Pulmonol 2010;45(2):120-126.

6. Wang W, Cavailler P, Ren P, Zhang J, Dong W, Yan H, et al. Molecular monitoring of causative viruses in child acute respiratory infection in endemo-epidemic situations in Shanghai. J Clin Virol. 2010;49(3):211218. doi:10.1016/j.jcv.2010.08.005

7. Zuccotti G, Dilillo D, Zappa A, Galli E, Amendola A, Martinelli M, et al. Epidemiological and clinical features of respiratory viral infections in hospitalized children during the circulation of influenza virus A(H1N1) 2009. Influenza Other Respi Viruses. 2011;5(6): e528-e534. doi:10.1111/j.1750-2659.2011.00264.x

8. Shen J, Zhu Q, Zeng M, Yu H. Detection and genome analysis of human bocavirus 1-4 from hospitalized children with acute lower respiratory tract infection and symptoms of wheezing in Shanghai. Int J Mol Med. 2013;32(6):1415-1420. doi:10.3892/ijmm.2013.1512

9. Chen YW, Huang YC, Ho TH, Huang CG, Tsao KC, Lin TY, et al. Viral etiology of bronchiolitis among pediatric inpatients in northern Taiwan with emphasis on newly identified respiratory viruses. J Microbiol Immunol Infect. 2014;47(2):116-121. doi:10.1016/j. jmii.2012.08.012

10. Ghietto LM, Majul D, Ferreyra Soaje P, Baumeister E, Avaro M, Insfrán C, et al. Comorbidity and high viral load linked to clinical presentation of respiratory human bocavirus infection. Arch Virol. 2015;160(1):117127. doi:10.1007/s00705-014-2238-5

11. Guo L, Wang Y, Zhou H, Wu C, Song J, et al. Differential Seroprevalence of human bocavirus species 1-4 in Beijing, China. PLoS One. 2012;7(6):e39644. doi:10.1371/journal.pone.0039644

12. Guo L, Gonzalez R, Xie Z, Zhou H, Liu C, Wu C, et al. Bocavirus in children with acute respiratory infection. Emerg Infect Dis. 2011;17(9):17751777. doi:10.3201/eid1709.110078

13. Pilger DA, Cantarelli VV, Amantea SL, Leistner-Segal S. Detection of human bocavirus and human metapneumovirus by real-time $\{\mathrm{PCR}\}$ from patients with respiratory symptoms in Southern Brazil. Mem Inst Oswaldo Cruz. 2011;106(1):56-60.

14. Proença-Modena JL, Gagliardi TB, de Paula FE, Iwamoto MA, Criado MF, Criado MF, et al. Detection of human bocavirus mRNA in respiratory secretions correlates with high viral load and concurrent diarrhea. PLoS One. 2011;6(6): e21083. doi:10.1371/journal.pone.0021083

15. Abdel-Moneim AS, Kamel MM, Al-Ghamdi AS, Al-Malky MIR. Detection of Bocavirus in Children Suffering from Acute Respiratory Tract Infections in Saudi Arabia. PLoS One. 2013;8(1):e55500. doi:10.1371/ journal.pone.0055500

16. Calvo C, García-García ML, Blanco C, Santos MJ, Pozo F, Pérez-Breña $\mathrm{P}$, et al. Human bocavirus infection in a neonatal intensive care unit. J Infect. 2008;57(3):269-271. doi:10.1016/j.jinf.2008.06.004

17. Longtin J, Bastien M, Gilca R, Leblanc E, De Serres G, Bergeron MG, et al. Human bocavirus infections in hospitalized children and adults. Emerg Infect Dis. 2008;14:217-221.

18. Douros K, Kotzia D, Kottaridi C, Giotas A, Boutopoulou B, Karakitsos $\mathrm{P}$, et al. Many children aged two to five years have a persistent presence of respiratory viruses in their nasopharynx. Acta Paediatr 2016;105(2):e89-e92. doi:10.1111/apa.13259

19. Meriluoto M, Hedman L, Tanner L, Simell V, Makinen M, Simell S, et al. Association of human bocavirus 1 infection with respiratory disease in childhood follow-up study Finland. Emerg Infect Dis. 2012;18(2):264271. doi:10.3201/eid1802.111293

20. Martin ET, Kuypers J, McRoberts JP, Englund JA, Zerr DM. Human Bocavirus 1 Primary Infection and Shedding in Infants. J Infect Dis 2015;212(4):516-524.

21.Christensen A, Nordbø SA, Krokstad S, Rognlien Wesenberg AG, Døllner H. Human bocavirus in children: Mono-detection, high viral load and viraemia are associated with respiratory tract infection. J Clin Virol. 2010;49:158-162. doi:10.1016/j.jcv.2010.07.016

22. Deng Y, Gu X, Zhao X, Luo J, Luo Z, et al. High viral load of human bocavirus correlates with duration of wheezing in children with severe lower respiratory tract infection. PLoS One. 2012;7(3):e34353. doi:10.1371/journal.pone.0034353

23.Zhao B, Yu X, Wang C, Teng Z, Wang C, Shen J, et al. High Human Bocavirus Viral Load Is Associated with Disease Severity in Children under Five Years of Age. PLoS One. 2013;8(4):e62318. doi:10.1371/ journal.pone.0062318

24.Zhou L, Zheng S, Xiao Q, Ren L, Xie X, Luo J, et al. Single detection of human bocavirus 1 with a high viral load in severe respiratory tract infections in previously healthy children. BMC Infect Dis. 2014;14:424. Doi:10.1186/1471-2334-14-424

25. Boom R, Sol CJ, Salimans MM, Jansen CL, Wertheim-van Dillen PM, Noordaa VDJ et al. Rapid and simple method for purification of nucleic acids. J Clin Microbiol 1990;28(3):495-503.

26. Allander T, Tammi MT, Eriksson M, Bjerkner A, Tiveljung-Lindell A, Andersson B. Cloning of a human parvovirus by molecular screening of respiratory tract samples. Proc Natl Acad Sci U S A. 2005;102(36):12891-12896. doi:10.1073/pnas.0504666102

27. Ghietto LM, Cámara A, Zhou Y, Pedranti M, Ferreyra S, et al. High prevalence of human bocavirus 1 in infants with lower acute respiratory tract disease in Argentina, 2007 - 2009. Brazilian J Infect Dis. 2012;16(1):38-44. doi:10.1016/S1413-8670(12)70272-6 
28. Ghietto LM, Cámara A, Cámara J, Adamo MP. High frequency of human bocavirus 1 DNA in infants and adults with lower acute respiratory infection. J Med Microbiol. 2012;61(4):548-551. doi:10.1099/ jmm.0.035600-0

29. Kapoor A, Simmonds P, Slikas E, Li L, Bodhidatta L, Sethabutr O, et al. Human bocaviruses are highly diverse, dispersed, recombination prone, and prevalent in enteric infections. J Infect Dis 2010;201(11):16331643. doi:10.1086/652416

30. Wishaupt JO, van der Ploeg T, de Groot R, Versteegh FGA, Hartwig NG. Single- and multiple viral respiratory infections in children: disease and management cannot be related to a specific pathogen. BMC Infect Dis. 2017;17:62. doi:10.1186/s12879-016-2118-6

31. Wishaupt JO, Ploeg T Van Der, Smeets LC, Groot R De, Versteegh FGA, Hartwig NG, et al. Pitfalls in interpretation of CT-values of RT-PCR in children with acute respiratory tract infections. J Clin Virol. 2017;90:16.

32. Marcone DN, Culasso A, Carballal G, Campos R, Echavarría M. Genetic diversity and clinical impact of human rhinoviruses in hospitalized and outpatient children with acute respiratory infection, Argentina. J Clin Virol. 2014;61(4):558-564. doi:10.1016/j.jcv.2014.10.006

33. Clay CC, Reader JR, Gerriets JE, Wang TT, Harrod KS, et al. Enhanced Viral Replication and Modulated Innate Immune Responses in Infant Airway Epithelium Following H1N1 Infection. J Virol. 2014;88(13):7412-7425. doi:10.1128/JVI.00188-14

34. Whitsett JA, Alenghat T. Respiratory epithelial cells orchestrate pulmonary innate immunity. Nat Immunol 2015;16:27-35. doi:10.1038/ni.3045

35. Moreno La, Eguizábal L, Ghietto LM, Bujedo E, Adamo MP. Human bocavirus respiratory infection in infants in Córdoba, Argentina. Arch Argent Pediatr 2014;112:70-74. doi:10.1590/S032500752014000100013

36. Lindner J, Karalar L, Zehentmeier S, Plentz A, Pfister H, Struff W, et al. Humoral Immune Response Against Human Bocavirus VP2 VirusLike Particles. Viral Immunol. 2008;21(4):443-449. doi:10.1089/ vim.2008.0045

37. Kantola K, Hedman L, Allander T, Jartti T, Lehtinen P, Ruuskanen 0 , et al. Serodiagnosis of human bocavirus infection. Clin Infect Dis. 2008;46(4):540-546. doi:10.1086/526532

38. Endo R, Ishiguro N, Kikuta H, Teramoto S, Shirkoohi R, Ma X, et al. Seroepidemiology of human bocavirus in Hokkaido Prefecture, Japan. J Clin Microbiol. 2007;45:3218-3223. doi:10.1128/JCM.02140-06
39. Kantola K, Hedman L, Arthur J, Alibeto A, Delwart E, Jartti T, et al. Seroepidemiology of human bocaviruses 1-4. J Infect Dis. 2011;204(9):1403-1412. doi:10.1093/infdis/jir525

40. Kantola K, Hedman L, Tanner L, Simell V, Mäkinen M, Partanen J, et al. B-cell responses to human bocaviruses 1-4: New insights from a childhood follow-up study. PLoS One. 2015;10:e0139096. doi:10.1371/journal.pone.0139096

41. Li X, Kantola K, Hedman L, Arku B, Hedman K, Söderlund-Venermo M. Original antigenic sin with human bocaviruses 1-4. J Gen Virol. 2015;96(10):3099-3108. doi:10.1099/jgv.0.000253

42. Nascimento-Carvalho CM, Cardoso MRA, Meriluoto M, Kemppainen K, Kantola K, Ruuskanen O, et al. Human bocavirus infection diagnosed serologically among children admitted to hospital with communityacquired pneumonia in a tropical region. J Med Virol. 2012;84(2):253258. doi:10.1002/jmv.22268

43. Nair H, Simões EAF, Rudan I, Gessner BD, Azziz-Baumgartner E, Zhang JSF, et al. Global and regional burden of hospital admissions for severe acute lower respiratory infections in young children in 2010: A systematic analysis. Lancet. 2013;381(9875):1380-1390. doi:10.1016/S0140-6736(12)61901-1

44. Cantais A, Mory O, Pillet S, Verhoeven PO, Bonneau J, Patural H, et al. Epidemiology and microbiological investigations of communityacquired pneumonia in children admitted at the emergency department of a university hospital. J Clin Virol. 2014;60(4):402-407. doi:10.1016/j.jcv.2014.05.006

45. Lowen AC, Steel J. Roles of Humidity and Temperature in Shaping Influenza Seasonality. J Virol. 2014;88(14):7692-7695. doi:10.1128/ JVI.03544-13

46. Tang JW, Loh TP. Correlations between climate factors and incidence-a contributor to RSV seasonality. Rev Med Virol. 2014;24(1):15-34. doi:10.1002/rmv.1771

47. Goutaki M, Haidopoulou K, Pappa S, Tsakiridis P, Frydas E, Eboriadou $\mathrm{M}$, et al. The role of TLR4 and CD14 polymorphisms in the pathogenesis of respiratory syncytial virus bronchiolitis in greek infants. Int J Immunopathol Pharmacol. 2014;27(4):563-572.

48. Herrera-Ramos E, López-Rodríguez M, Ruíz-Hernández JJ, Horcajada JP, Borderías L, et al. Surfactant protein A genetic variants associate with severe respiratory insufficiency in pandemic influenza A virus infection. Crit Care 2014;18(3):R127. doi:10.1186/cc13934 